\title{
Lotus glaber Mill: comparison of some morphological-physiological characters between an induced autotetraploid population and diploid cultivars
}

\author{
M. Barufaldi ${ }^{1}$, P. Sastre-Vázquez ${ }^{2}$, Y. Villacampa ${ }^{3}$, \\ F. García-Alonso ${ }^{3}$, J. A. Reyes ${ }^{3} \&$ A. Alonso ${ }^{1}$ \\ ${ }^{1}$ Cátedra de Genética y Fitotecnia, \\ Facultad de Agronomía de Azul-UNCPBA, Argentina \\ ${ }^{2}$ Área de Matemáticas, Facultad de Agronomía de Azul-UNCPBA, \\ Argentina \\ ${ }^{3}$ Dpto. Matemática Aplicada, Universidad de Alicante, Spain
}

\begin{abstract}
Lotus glaber Mill, a diploid forage legume $(2 \mathrm{n}=2 \mathrm{x}=12)$, has successfully adapted to the ecological characteristics of the Flooding Pampas region of the Province of Buenos Aires, Argentina. This species is highly valued, basically due to its ability to adapt to soils that do not allow other forage legumes to prosper, as well as for its high nutritional value.

A genetic improvement programme of the species resulted in an induced autotetraploid population known as "Leonel" $(2 n=4 x=24)$. Generally speaking, induced autotetraploid forms are larger and also more vigorous and productive than their diploid counterparts. Although fewer seeds are produced, they are heavier.

This article compares certain morphological-physiological characters of the "Leonel" population and diploid cultivars. The characteristics evaluated were length (CFL), width (CFW), area (CFA), length/width ratio (L/W) of the central foliolae of the first expanded leaf from the stem apex and the vigour of the plants (V) from May to December. The following variables were also studied: days to flowering (BFP), air biomass, expressed as green material (GM) and dry material (DM), weight of a thousand seeds (WS), number of seeds per pod (NS), number of empty seeds per pod (ES) and the number of full seeds per pod (FS).

Variance analysis was carried out with a completely random design using two factors, cytotype and month, for the following variables: CFL, CFW, CFA, L/W and V. For the remaining variables, variance analysis was carried out with a completely random design using one factor: cytotype. The Duncan's Test, using a level of confidence of 5\%, was used to compare the mean values. In addition, analysis of the $\mathrm{L} / \mathrm{W}$ ratio allowed the form of the foliolae to be determined.

Keywords: modelling; Lotus glaber Mill, induced autotetraploid, forage legume, natural pasture, grasslands.
\end{abstract}




\section{Introduction}

In Argentina, the Flooding Pampas region of Buenos Aires province presents a wide prevalence of lowland fields; suitable for the breeding of bovines, whose main resource of forage are the natural grasslands. The main characteristic of this plain is to present a very scarce slope $(0.1$ to $0.2 \%)$, leading to serious problems with the flow of the water.

The region occupies approximately 9.000 .000 hectares, $67 \%$ of the area presents soils with flooding problems, salinity, alkalinity, low permeability, low phosphorus levels and high phreatic water.

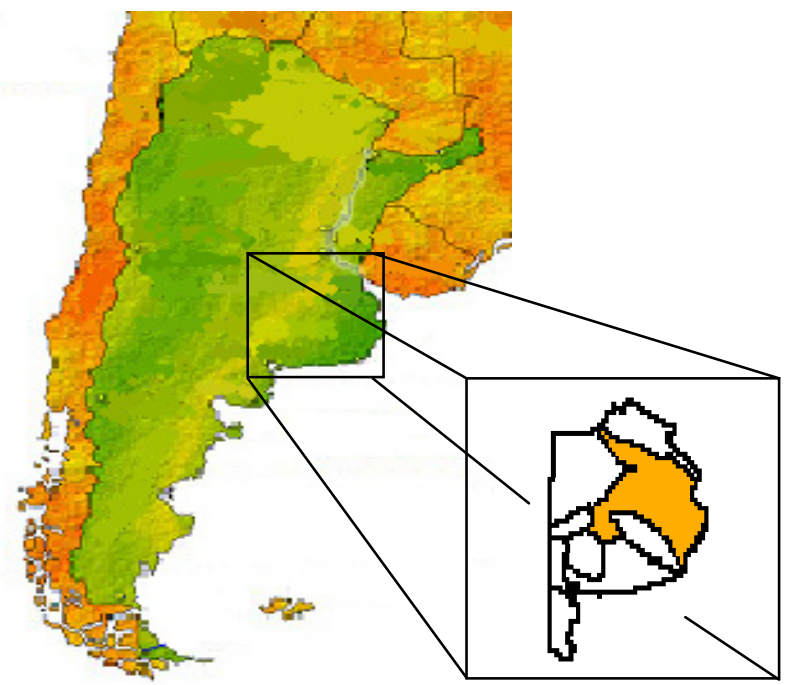

Figure 1: Argentina, Buenos Aires's Province, region of Flooding Pampas.

The climate of the region is sub humid with tendency to humid (1973-2003). The annual rain is $1100 \mathrm{~mm}$ in the northeast and $800 \mathrm{~mm}$ in the southwest. Theoretically, the global heating can increase the rains in the region, as well as its variability, accentuating the alternation of floods and droughts. The annual mean temperature is $13^{\circ} \mathrm{C}$ to $16^{\circ} \mathrm{C}$, winter of $7^{\circ} \mathrm{C}$ to $9^{\circ} \mathrm{C}$ and the summery of $20^{\circ} \mathrm{C}$ at $23^{\circ} \mathrm{C}$ (Salies [1]).

Lotus glaber Mill, is a forage perennial legume diploid $(2 \mathrm{n}=2 \mathrm{x}=12$ chromosomes) native from Europe. The productive cycle of this specie is during spring-summer- autumn. L. glaber is well known for their high nutritional quality, to its aptitude to natural sowing and anti-bloating.

It is a long-day specie that requires a photoperiod of about 16 hours to complete the floral induction. The inflorescence is a typical umbellate with 2-8 flowers joined by short pedicel to a long peduncle. Flowers are bisexual and are pollinated by insects; cross-pollination is usual, and this specie is largely, though not completely, self-incompatible (Fairey and Smith [2]). Flowering is indeterminate, continuing for a long time, since November to March. The pod is 
linear, cylindrical with 15 to 20 seeds. The pods dehiscence or pop open on maturity and the seeds are scattered. After the requirements for floral initiation have been met, inflorescences, seed pods and seeds of varying maturity are produced throughout the reproductive stage.

It has shown an excellent adaptation to the ecological characteristics of de Flooding Pampas (Pampa Deprimida), especially for its adaptation to seasonal cycles of drought and flood and soil restrictions. The soils colonized by lotus usually have a poor drainage, moderate sodium contents and low concentrations of available phosphorus.

As of a genetic improvement programme was obtained an induced tetraploid population called Leonel $(2 n=4 x=24)$, which arises through colchicine treatment of seedlings obtained from seeds from naturalized L. glaber populations. In general, the induced autopolyploids in some forage species show better: establishment and plant vigour; higher in vitro digestibility and forage production, and better performance in response to such adverse factors, as disease, frost and drought, than corresponding diploids (Barufaldi et al. [3]).

The drawback of induced autotetraploid is the reduced seed production, due to irregularities in their meioses, which lead to the formation of a significant proportion of unviable gametes, responsible for reduced fertility when compared with diploid forms (Barufaldi et al. [4]).

However studies carried out on autotetraploid Trifolium pratense (Dennis, [5]) and research carried out on Secale cereale, (Pérez [6]; Funes et al. [7]), have reported achieving increases in seed production of induced autotetraploid forms due to natural and artificial selection, after first generations of multiple-crossing.

In the present work, some morpho-physiological characters were compared between the population "Leonel" and two diploids varieties, with the purpose of finding out if the induced polyploidy produces important modifications in those characters.

The process of improvement that at the moment it is developing in this germplasm, which presents an important genetic variability for high agronomic traits, will allow the obtaining of tetraploid varieties with a suitable genetic base to be incorporate to the environment of the grassland like an important forage resource.

\section{Materials and methods}

The experimental data were obtained at the Agronomy Faculty in Azul, Buenos Aires Province $\left(36^{\circ} 45^{\prime} \mathrm{S}, 59^{\circ} 50^{\prime} \mathrm{W}\right.$ and $132 \mathrm{~m}$ above sea level), Argentina, from May 2007 to July 2008. The plant material was taken from the Leonel population (tetraploid cytotype), and two diploid cytotypes: cv Chajá and cv Pampa INTA. Seeds were left to germinate in accordance with ISTA norms [8]. The seedlings obtained were transplanted in 2-litre plastics planters (27 for tetraploid cytotype and 26 for diploid cytotype), with soil and compost, in a greenhouse. When they reached the height of $15 \mathrm{~cm}$ they were permanently transplanted in 5-litre plastic planters and remained in the open air, under optimal irrigation condition and without nutritive restrictions. Three stalks were taken at random from each plant, 
and from each of them the central foliolae corresponding to the first expanded leaf from the apex was utilised. For each foliolae, monthly measurements were taken of: 1) The central foliolae's length in centimetres, from the foliar lamina's points of insertion in the petiole to the foliolae's apex (CFL); 2) The central foliolae's width measured in centimetres at an angle perpendicular to the central nerve of the foliolae's widest point (CFW). On the basis of this data, the central foliolae's area was estimated using the model presented by Barufaldi et al. [4] (CFA).

The relationship length/width was also calculated in order to determine the foliolae's shape (Hickey [9]). In order to compare the seasonal growth, it was evaluated the plant's vigour using a scale from one to seven, being one the worst and seven the best. For the variable beginning of flowering period (BFP), the days lapsed from the 1/11 until the appearances of the first flower opened up, in each plant, were taken. Starting from ends of January and until beginning of March of the year 2008, when the pods were mature, these were harvested manually. The storage was carried out in individual envelopes identified by cytotypes. Thirty and one pods were taken at radon from each cytotype and it was counted the number of seeds: full (FS) and empty (ES), per pod. The weight of 1000 seeds (WS) was determined taking the average of 5 repetitions of 100 seeds each and the value was extrapolated to 1000 seeds.

With the objective of determining the air biomass, in the month of July of 2008 , the 15 more vigorous plants of each cytotype were cut manually. The cut was carried out to a height 10 centimetres. The biomass area was expressed as green matter (GM) and dry matter (DM). The determinations of dry matter were carried out in ventilated stove to 60 -centigrade degrees until reaching constant weight.

\section{Data analysis}

From the analysis of the variable CFL, CFW, and CFA significant differences were detected for the interaction (cytotype * month), not occurring the same for the variable V. Means of all the variables were superior for the germ plasm tetraploid. Monthly means corresponding to the variables in which an interaction (cytotype * month) was detected, can be observed in Tables 1 and 2.

During the month of September both cytotypes presented their bigger width of the central foliolae, and in December the minor. On the other hand, the smallest value for the longitude in both cytotypes was presented in the month of July and the biggest value in November.

The biggest area in the central foliolae corresponded to the month of September in both cytotypes. The lower area corresponded to the month of December for both cytotypes. On the other hand, the smallest value in both cytotypes was presented in the month of December.

The analysis of the relationship L/W allowed determining the forms of the foliolaes. From May until October, the foliolaes presented narrowly obovate form in both cytotypes, while during November and December both presented oblanceolate forms (Table 3). 
Table 1: Comparison of length (CFL) and width (CFW) of the central foliolae of the first expanded leaf between the diploid and tetraploid cytotype of L. glaber Mill.

\begin{tabular}{|c|c|c|c|c|c|}
\hline CHARACTER & MOUNTH & СУТОТУРЕ & $M E A N \S$ & $R A N G E$ & $\begin{array}{l}C V \\
\%\end{array}$ \\
\hline \multirow[t]{8}{*}{ CFL (cm) } & MAY (5) & $\begin{array}{l}2 \mathrm{x} \\
4 \mathrm{x}\end{array}$ & $\begin{array}{l}0.926 \pm 0.139 \\
* * * \\
1.322 \pm 0.187\end{array}$ & $\begin{array}{l}0.61- \\
1.31 \\
0.92- \\
1.62 \\
\end{array}$ & $\begin{array}{l}15.07 \\
14.18\end{array}$ \\
\hline & JUNE (6) & $\begin{array}{l}2 \mathrm{x} \\
4 \mathrm{x}\end{array}$ & $\begin{array}{l}0.758 \pm 0.110 \\
* * * \\
1.163 \pm 0.151\end{array}$ & $\begin{array}{l}0.50- \\
1.02 \\
0.80- \\
1.50\end{array}$ & $\begin{array}{l}14.51 \\
12.96\end{array}$ \\
\hline & JULY (7) & $\begin{array}{l}2 \mathrm{x} \\
4 \mathrm{x}\end{array}$ & $\begin{array}{l}0.734 \pm 0.106 \\
* * * \\
1.039 \pm 0.168\end{array}$ & $\begin{array}{l}0.50- \\
1.00 \\
0.70- \\
1.50 \\
\end{array}$ & $\begin{array}{l}14.46 \\
13.09\end{array}$ \\
\hline & AUGUST (8) & $\begin{array}{l}2 \mathrm{x} \\
4 \mathrm{x}\end{array}$ & $\begin{array}{l}0.953 \pm 0.184 \\
* * * \\
1.175 \pm 0.154\end{array}$ & $\begin{array}{l}0.58- \\
1.22 \\
0.82- \\
1.50 \\
\end{array}$ & $\begin{array}{l}19.31 \\
14.09\end{array}$ \\
\hline & $\begin{array}{l}\text { SEPTEMBER } \\
\text { (9) }\end{array}$ & $\begin{array}{l}2 \mathrm{x} \\
4 \mathrm{x}\end{array}$ & $\begin{array}{l}1.184 \pm 0.129 \\
* * * \\
1.512 \pm 0.221\end{array}$ & $\begin{array}{l}0.83- \\
1.51 \\
1.02- \\
2.00\end{array}$ & $\begin{array}{l}10.90 \\
14.60\end{array}$ \\
\hline & OCTOBER (10) & $\begin{array}{l}2 \mathrm{x} \\
4 \mathrm{x}\end{array}$ & $\begin{array}{l}1.185 \pm 0.150 \\
* * * \\
1.517 \pm 0.192\end{array}$ & $\begin{array}{c}0.90-1.62 \\
1.15- \\
2.10 \\
\end{array}$ & $\begin{array}{l}12.68 \\
12.66\end{array}$ \\
\hline & $\begin{array}{l}\text { NOVEMBER } \\
\text { (11) }\end{array}$ & $\begin{array}{l}2 \mathrm{x} \\
4 \mathrm{x}\end{array}$ & $\begin{array}{l}1.242 \pm 0.103 \\
* * * \\
1.530 \pm 0.144\end{array}$ & $\begin{array}{l}1.11- \\
1.80 \\
1.22- \\
2.00 \\
\end{array}$ & $\begin{array}{l}8.32 \\
9.40\end{array}$ \\
\hline & $\begin{array}{l}\text { DECEMBER } \\
\text { (12) }\end{array}$ & $\begin{array}{l}2 \mathrm{x} \\
4 \mathrm{x}\end{array}$ & $\begin{array}{l}1.190 \pm 0.060 \\
* * * \\
1.492 \pm 0.148\end{array}$ & $\begin{array}{l}1.00- \\
1.32 \\
1.12- \\
1.80 \\
\end{array}$ & $\begin{array}{l}5.05 \\
9.94\end{array}$ \\
\hline \multirow[t]{2}{*}{ CFW (cm) } & MAY (5) & $\begin{array}{l}2 \mathrm{x} \\
4 \mathrm{x}\end{array}$ & $\begin{array}{l}0.484 \pm 0.080 \\
* * * \\
0.719 \pm 0.122\end{array}$ & $\begin{array}{l}0.40- \\
0.70 \\
0.50- \\
1.00 \\
\end{array}$ & $\begin{array}{l}16.01 \\
16.91\end{array}$ \\
\hline & JUNE (6) & $\begin{array}{l}2 \mathrm{x} \\
4 \mathrm{x}\end{array}$ & $\begin{array}{l}0.414 \pm 0.060 \\
* * * \\
0.697 \pm 0.120\end{array}$ & $\begin{array}{l}0.30- \\
0.60 \\
0.50- \\
1.00\end{array}$ & $\begin{array}{l}14.49 \\
16.65\end{array}$ \\
\hline
\end{tabular}


Table 1: $\quad$ Continued.

\begin{tabular}{|c|c|c|c|c|}
\hline JULY (7) & $\begin{array}{l}2 \mathrm{x} \\
4 \mathrm{x} \\
\end{array}$ & $\begin{array}{l}0.400 \pm 0.060 * * * \\
0.600 \pm 0.110\end{array}$ & $\begin{array}{l}0.30-0.60 \\
0.40-0.90 \\
\end{array}$ & $\begin{array}{l}14.87 \\
18.37 \\
\end{array}$ \\
\hline AUGUST (8) & $\begin{array}{l}2 \mathrm{x} \\
4 \mathrm{x}\end{array}$ & $\begin{array}{l}0.479 \pm 0.817 * * * \\
0.621 \pm 0.108\end{array}$ & $\begin{array}{l}0.30-0.70 \\
0.40-0.90 \\
\end{array}$ & $\begin{array}{l}17.07 \\
17.44 \\
\end{array}$ \\
\hline SEPTEMBER (9) & $\begin{array}{l}2 \mathrm{x} \\
4 \mathrm{x} \\
\end{array}$ & $\begin{array}{l}0.524 \pm 0.853 * * * \\
0.730 \pm 0.108\end{array}$ & $\begin{array}{l}0.40-0.80 \\
0.50-1.00 \\
\end{array}$ & $\begin{array}{l}16.26 \\
14.86 \\
\end{array}$ \\
\hline OCTOBER (10) & $\begin{array}{l}2 \mathrm{x} \\
4 \mathrm{x}\end{array}$ & $\begin{array}{l}0.501 \pm 0.537 * * * \\
0.617 \pm 0.107\end{array}$ & $\begin{array}{l}0.40-0.61 \\
0.40-0.90 \\
\end{array}$ & $\begin{array}{l}10.73 \\
17.40 \\
\end{array}$ \\
\hline NOVEMBER (11) & $\begin{array}{l}2 \mathrm{x} \\
4 \mathrm{x} \\
\end{array}$ & $\begin{array}{l}0.476 \pm 0.625^{* * *} \\
0.621 \pm 0.109\end{array}$ & $\begin{array}{l}0.40-0.60 \\
0.40-1.00 \\
\end{array}$ & $\begin{array}{l}13.14 \\
17.47 \\
\end{array}$ \\
\hline DECEMBER (12) & $\begin{array}{l}2 \mathrm{x} \\
4 \mathrm{x}\end{array}$ & $\begin{array}{l}0.393 \pm 0.596 * * * \\
0.540 \pm 0.102\end{array}$ & $\begin{array}{l}0.30-0.50 \\
0.40-0.80\end{array}$ & $\begin{array}{l}15.16 \\
18.96 \\
\end{array}$ \\
\hline
\end{tabular}

$\S$ Mean values \pm Standard deviation; $* * *$ significant differences $\mathrm{P}<0.001$. 2x: cytotype diploid; $4 \mathrm{x}$ : cytotype tetraploid. cv \%: variation coefficient.

In Table 4, the following characters are compared: beginning of flowering period, biomass aerial, weight of thousand seeds and number of seeds, empty seeds and full seeds per pod between diploid and tetraploid cytotype of L. glaber Mill.

Significant differences were detected among the means of two cytotypes, in most of the variables. However, for the character beginning of flowering period, the difference of 5 days was not statistically significant. Concerning, to this last character, tetraploid germplasm presented an inferior average, with a smaller range and, a phenotypic variability (expressed as variation coefficient) superior that diploid cultivars. Tetraploid germplasm presented an average of biomass aerial (expressed as green matter and dry matter) superior, with bigger ranges and an important phenotypic variation.

Regarding the evaluated components of the production of seeds: the weight of a thousand seeds is superior in the tetraploid, while the number of seeds per pod and the number of full and empty seeds per pod were higher in the diploid. In all the cases, the ranges for these variables were superior for the diploid cultivars. Also, phenotypic variability, expressed as variation coefficients $(\mathrm{CV} \%)$ is important for the characters: number of seeds per pod and number of full seeds per pod (Table 4).

Results obtained in the estimate of the seasonal growth, through the vigour of the individual plants, are presented in Table 5.

Differences among the means of plant vigour were, during every evaluated month, significantly superior in tetraploid germplasm. During period of autumnal growth (May and June) diploid cytotype presented vigour of good to very good, while the tetraploid cytotype presented very good vigour. 
Table 2: Comparison of the central foliolae area (CFA) of the first expanded leaf among the diploid and tetraploid cytotype of $L$. glaber Mill.

\begin{tabular}{|c|c|c|c|c|c|}
\hline CHARACTER & MOUNTH & СУТОТУРЕ & $M E A N \S$ & $R A N G E$ & $\begin{array}{l}C V \\
\%\end{array}$ \\
\hline \multirow[t]{8}{*}{ CFA $\left(\mathrm{cm}^{2}\right)$} & MAY (5) & $\begin{array}{l}2 \mathrm{x} \\
4 \mathrm{x}\end{array}$ & $\begin{array}{l}0.501 \pm 0.139 \\
* * * \\
0.771 \pm 0.215 \\
\end{array}$ & $\begin{array}{l}0.35-0.89 \\
0.38-1.27\end{array}$ & $\begin{array}{l}27.85 \\
27.85\end{array}$ \\
\hline & JUNE (6) & $\begin{array}{l}2 \mathrm{x} \\
4 \mathrm{x}\end{array}$ & $\begin{array}{l}0.374 \pm 0.108 \\
* * * \\
0.732 \pm 0.205\end{array}$ & $\begin{array}{l}0.17-0.71 \\
0.38-1.27\end{array}$ & $\begin{array}{l}28.82 \\
28.00\end{array}$ \\
\hline & JULY (7) & $\begin{array}{l}2 \mathrm{x} \\
4 \mathrm{x}\end{array}$ & $\begin{array}{l}0.350 \pm 0.107 \\
* * * \\
0.560 \pm 0.195\end{array}$ & $\begin{array}{c}0.17- \\
0.71 \\
0.21-1.09 \\
\end{array}$ & $\begin{array}{l}30.60 \\
34.71\end{array}$ \\
\hline & AUGUST (8) & $\begin{array}{l}2 \mathrm{x} \\
4 \mathrm{x}\end{array}$ & $\begin{array}{l}0.491 \pm 0.147 \\
* * * \\
0.598 \pm 0.191\end{array}$ & $\begin{array}{l}0.17- \\
0.89 \\
0.21- \\
1.09\end{array}$ & $\begin{array}{l}30.00 \\
32.00\end{array}$ \\
\hline & $\begin{array}{l}\text { SEPTEMBER } \\
\text { (9) }\end{array}$ & $\begin{array}{l}2 \mathrm{x} \\
4 \mathrm{x}\end{array}$ & $\begin{array}{l}0.573 \pm 0.153 \\
* * * \\
0.790 \pm 0.192\end{array}$ & $\begin{array}{l}0.35- \\
1.07 \\
0.38- \\
1.27 \\
\end{array}$ & $\begin{array}{l}26.77 \\
24.25\end{array}$ \\
\hline & OCTOBER (10) & $\begin{array}{l}2 \mathrm{x} \\
4 \mathrm{x}\end{array}$ & $\begin{array}{l}0.530 \pm 0.097 \\
* * * \\
0.591 \pm 0.189\end{array}$ & $\begin{array}{l}0.35-0.73 \\
0.21- \\
1.09 \\
\end{array}$ & $\begin{array}{l}18.22 \\
32.08\end{array}$ \\
\hline & $\begin{array}{l}\text { NOVEMBER } \\
\text { (11) }\end{array}$ & $\begin{array}{l}2 \mathrm{x} \\
4 \mathrm{x}\end{array}$ & $\begin{array}{l}0.485 \pm 0.112 \\
* * * \\
0.599 \pm 0.192\end{array}$ & $\begin{array}{l}0.35- \\
0.71 \\
0.21- \\
1.27 \\
\end{array}$ & $\begin{array}{l}23.15 \\
32.04\end{array}$ \\
\hline & $\begin{array}{l}\text { DECEMBER } \\
\text { (12) }\end{array}$ & $\begin{array}{l}2 \mathrm{x} \\
4 \mathrm{x}\end{array}$ & $\begin{array}{l}0.337 \pm 0.107 \\
* * * \\
0.455 \pm 0.181\end{array}$ & $\begin{array}{l}0.17- \\
0.53 \\
0.21- \\
0.91\end{array}$ & $\begin{array}{l}31.80 \\
39.73\end{array}$ \\
\hline
\end{tabular}

$\S$ Mean values \pm Standard deviation; $* * *$ significant differences $\mathrm{P}<0.001$. 2x: cytotype diploid; $4 \mathrm{x}$ : cytotype tetraploid, cv \%: variation coefficient.

Table 3: $\quad$ Foliolae forms in both cytotypes.

\begin{tabular}{|c|c|}
\hline Foliolae forms & Months \\
\hline Narrowly obovate & May- June - July - August - September - \\
October
\end{tabular}


Table 4: $\quad$ Comparison of characters.

\begin{tabular}{|c|c|c|c|c|}
\hline CHARACTER & CYTOTYPE & $M E A N \S$ & RANGE & CV \% \\
\hline $\begin{array}{l}\text { BPF } \\
\text { (Beginning of } \\
\text { flowering) }\end{array}$ & $\begin{array}{l}2 x \\
4 x\end{array}$ & $\begin{array}{l}27 \pm 8.599 \mathrm{~ns} \\
22 \pm 9.922\end{array}$ & $\begin{array}{r}9-45 \\
10-36\end{array}$ & $\begin{array}{l}36.54 \\
39.00\end{array}$ \\
\hline $\begin{array}{l}\mathrm{GV}(\mathrm{g}) \\
\text { (Green matter) }\end{array}$ & $\begin{array}{l}2 x \\
4 x\end{array}$ & $\begin{array}{l}21.33 \pm 10.712 \\
32.46 \pm 11.29\end{array}$ & $\begin{array}{l}8.00-46.00 \\
10.00-50.00\end{array}$ & $\begin{array}{l}50.21 \\
34.81\end{array}$ \\
\hline $\begin{array}{l}\mathrm{DM}(\mathrm{g}) \\
\text { (Dry matter) }\end{array}$ & $\begin{array}{l}2 x \\
4 x\end{array}$ & $\begin{array}{l}3.67 \pm 1.871 \text { * } \\
5.70 \pm 2.564\end{array}$ & $\begin{array}{l}1.60-8.40 \\
1.40-10.50\end{array}$ & $\begin{array}{l}50.95 \\
45.01\end{array}$ \\
\hline $\begin{array}{l}\text { WS }(g) \\
(1000, \text { seed } \\
\text { weight) }\end{array}$ & $\begin{array}{l}2 x \\
4 x\end{array}$ & $\begin{array}{l}1.028 \pm 0.049^{* * *} \\
1.584 \pm 0.029\end{array}$ & $\begin{array}{l}0.97-1.10 \\
1.55-1.63\end{array}$ & $\begin{array}{l}4.83 \\
2.02\end{array}$ \\
\hline $\begin{array}{l}\text { NS } \\
\text { (Seeds per } \\
\text { pods) }\end{array}$ & $\begin{array}{l}2 x \\
4 x\end{array}$ & $\begin{array}{c}17 \pm 6.889 \text { *** } \\
6 \pm 2.499\end{array}$ & $\begin{array}{l}6-29 \\
2-12\end{array}$ & $\begin{array}{l}41.15 \\
40.79\end{array}$ \\
\hline $\begin{array}{l}\text { ES } \\
\text { (Empty seeds } \\
\text { per pods) }\end{array}$ & $\begin{array}{l}2 x \\
4 x\end{array}$ & $\begin{array}{l}6 \pm 4.435^{* * *} \\
1 \pm 0.978\end{array}$ & $\begin{array}{c}2-21 \\
0-4\end{array}$ & $\begin{array}{c}73.92 \\
97.8\end{array}$ \\
\hline $\begin{array}{l}\text { FS } \\
\text { (Full seeds per } \\
\text { pods) }\end{array}$ & $\begin{array}{l}2 x \\
4 x\end{array}$ & $\begin{array}{c}11 \pm 6.493^{\text {*** }} \\
5 \pm 2.276\end{array}$ & $\begin{array}{l}2-26 \\
2-10\end{array}$ & $\begin{array}{l}58.01 \\
43.56\end{array}$ \\
\hline
\end{tabular}

$\S$ Mean values \pm Standard deviation;

ns: differences non significant $\mathrm{P}<0.05$

$*$; **; *** significant differences at $\mathrm{P}<0.05 ; \mathrm{P}<0.01$ and $\mathrm{P}<0.001$, respectively.

2x: cytotype diploid; $4 \mathrm{x}$ : cytotype tetraploid. cv \%: variation coefficient.

During the period of winter growth (July and August), the vigour average of the diploid was of good to very good, and the vigour average of the tetraploid was very good.

During the period of spring growth (September, October and November) average of vigour of the diploid was very good, while this value in the tetraploid was of very good to excellent.

Finally, during the beginning of the period of summery growth (December) both cytotypes presented an average of very good vigour. 
Table 5: $\quad$ Comparison of characteristic vigour of plants during the evaluated months.

\begin{tabular}{|c|c|c|c|c|c|}
\hline CHARACTER & MONTH & СYTOTYРЕ & $M E A N \S$ & $R A N G E$ & $C V \%$ \\
\hline \multirow[t]{8}{*}{ V } & MAY (5) & $\begin{array}{l}2 x \\
4 x\end{array}$ & $\begin{array}{l}4.54 \pm 0.76 \\
* \star * \\
5.85 \pm 0.95\end{array}$ & $\begin{array}{l}3-6 \\
4-7\end{array}$ & $\begin{array}{l}16.76 \\
16.21\end{array}$ \\
\hline & JUNE (6) & $\begin{array}{l}2 x \\
4 x\end{array}$ & 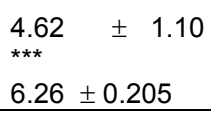 & $\begin{array}{l}2-7 \\
4-7\end{array}$ & $\begin{array}{l}23.80 \\
17.50\end{array}$ \\
\hline & ULY (7) & $\begin{array}{l}2 x \\
4 x\end{array}$ & $\begin{array}{l}4.38 \pm 1.13^{\text {***}} \\
5.78 \pm 1.42\end{array}$ & $\begin{array}{c}1-6 \\
2-7 \\
\end{array}$ & $\begin{array}{l}25.87 \\
24.63 \\
\end{array}$ \\
\hline & AUGUST (8) & $\begin{array}{l}2 x \\
4 x\end{array}$ & $\begin{array}{l}5.19 \pm 1.06 \text { ** } \\
6.00 \pm 1.21\end{array}$ & $\begin{array}{l}3-7 \\
2-7\end{array}$ & $\begin{array}{l}20.40 \\
20.15\end{array}$ \\
\hline & $\begin{array}{l}\text { SEPTEMBER } \\
\text { (9) }\end{array}$ & $\begin{array}{l}2 x \\
4 x\end{array}$ & $\begin{array}{l}5.62 \pm 1.13^{* *} \\
6.33 \pm 0.83\end{array}$ & $\begin{array}{l}4-7 \\
4-7\end{array}$ & $\begin{array}{l}20.20 \\
13.14\end{array}$ \\
\hline & $\begin{array}{l}\text { OCTOBER } \\
(10)\end{array}$ & $\begin{array}{l}2 x \\
4 x\end{array}$ & $\begin{array}{l}5.50 \pm 1.24 \\
6.37 \pm 0.79\end{array}$ & $\begin{array}{l}3-7 \\
4-7\end{array}$ & $\begin{array}{l}22.56 \\
12.43\end{array}$ \\
\hline & $\begin{array}{l}\text { NOVEMBER } \\
\text { (11) }\end{array}$ & $\begin{array}{l}2 x \\
4 x\end{array}$ & $\begin{array}{l}5.23 \pm 1.18^{* *} \\
6.00 \pm 0.96\end{array}$ & $\begin{array}{l}3-7 \\
4-7\end{array}$ & $\begin{array}{l}22.50 \\
16.01\end{array}$ \\
\hline & $\begin{array}{l}\text { DECEMBER } \\
(12)\end{array}$ & $\begin{array}{l}2 x \\
4 x\end{array}$ & $\begin{array}{l}5.31 \pm 0.84 \\
5.89 \pm 0.70\end{array}$ & $\begin{array}{l}4-7 \\
4-7\end{array}$ & $\begin{array}{l}15.78 \\
11.85\end{array}$ \\
\hline
\end{tabular}

$\S$ Mean values \pm Standard deviation;

*; **; *** significant differences at $\mathrm{P}<0.05 ; \mathrm{P}<0.01$ and $\mathrm{P}<0.001$, respectively. $2 \mathrm{x}$ : cytotype diploid; $4 \mathrm{x}$ : cytotype tetraploid. $\mathrm{cv} \%$ : variation coefficient.

\section{Conclusions}

The induced polyploidy produced the following effects:

a) Bigger size of the central foliolae without affecting the form of the foliolaes, bigger aerial biomass and bigger plant vigour.

b) Bigger weight average of the seeds and smaller number of seeds per pod.

The effect pointed out in a) it would indicate the possibility to increase the population's tetraploid aerial biomass through a program of recurrent selection. In the effect pointed out in b), although the biggest weight average in the seeds is 
a favourable character, the low number average of seeds per pod also appears as a detrimental effect.

Although the 5 days of difference among the beginning of the flowering in both cytotypes, were not statistically significant, if the reproductive characteristics of the species are considered, (period of flowering and of very extensive formation of pod, and the high dehiscence of the pods), the results would indicate the possibility to select in favour of plants with an earlier flowering, concentrating this way the flowering period and maturation of pod period on a briefer period in the tetraploid, the results would indicate the possibility to select in favour of plants with an earlier flowering. This way the flowering and maturation of pods would concentrate on a briefer period, in the tetraploid. This would facilitate to increase the production average of seeds at field.

\section{References}

[1] Salies, A. R. (2008). Suelos de campos bajos de la Pampa Deprimida. Actas XXI Congreso de la Ciencia del Suelo. San Luis, Potrero de los Funes, 13-16 May.

[2] Fairey, D. T. and Smith, R. R. (1994). Seed production in Birdsfoot Trefoil, Lotus Species. In: Trefoil: The Science and Technology of Lotus. CCSA Special Publication. Beuselink P.R. (ed). Number 28. pp. 145-166.

[3] Barufaldi, M.; Villacampa, Y.; Sastre-Vázquez, P.; García-Alonso and Reyes, J.A. (2007b). Lotus glaber Mill. Induced autotetraploid: new forage resource for the Flooding Pampas. In: Ecosystems and sustainable development VI. Tiezzi, E.; Marques, J.C.; Brebbia, C.A. and Jorgensen S.E (Eds). WIT Transactions on Ecology and the Environment, V 106, 2007 WIT Press. pp. 69-79.

[4] Barufaldi, M.; Villacampa, Y.; Sastre-Vázquez; P. and Verdú, F. (2007a). A system study of lotus's leaf area. Kybernetes. V 36, $\mathrm{N}^{\circ} 36$. pp. 225-235.

[5] Dennis, B. A. (1980). Mejoramiento genético de la producción de semilla de Trifolium pratense L. autotetraploide. In: Producción moderna de semillas. Ed. Hemisferio Sur. pp.276-290.

[6] Pérez, J. (1980). La poliploidía inducida como método de mejora del centeno forrajero. Actas IV Congreso Latinoamericano de Genética. 2: 457463.

[7] Funes, N.; Salaberry M. T.; Echeverría M. M; Luchini, A. and Rodríguez, R H. (2001). Efecto de la duplicación cromosómica en un cultivar de centeno (Secale cereale L.). Actas XXX Congreso Argentino de Genética. Mar del Plata, 16-19 September. p. 115.

[8] International Seed Testing Association (ISTA). Suiza 2002. Rules for seed testing. Chapter 5: Germination 5 A1- 5 A27.

[9] Hickey, L. J. (1974). Clasificación de la arquitectura de las hojas de dicotiledóneas. Boletín de la Sociedad Argentina de Botánica. V. XVI (-2): pp. 1-27. 